\title{
Adaptation of Individual Work Performance Questionnaire (IWPQ) into Bahasa Indonesia
}

Widyastuti, Tria $\triangle$

Faculty of Psychology, Universitas Gadjah Mada, Yogyakarta, Indonesia (triawidya06@gmail.com)

Hidayat, Rahmat

Faculty of Psychology, Universitas Gadjah Mada, Yogyakarta, Indonesia (r.hidayat@ugm.ac.id)

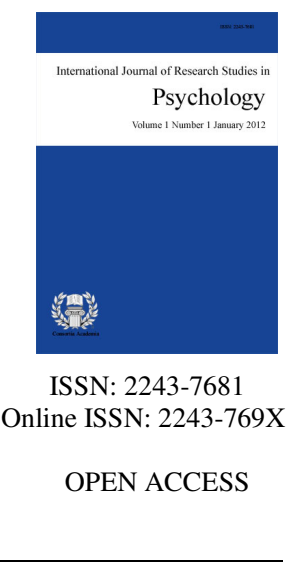

Received: 16 August 2018

Revised: 22 October 2018

Accepted: 16 November 2018 DOI: $10.5861 /$ ijrsp.2018.3020

\begin{abstract}
Research in work performance involving employees from different types of jobs is needed. Therefore, there is a necessity of generic instrument in work performance. However, most instruments measuring individual work performance are only developed for specific purposes in particular jobs. Thus it is not appropriate to utilize in a research involving workers from different types of jobs. One of generic instruments measuring work performance is Individual work performance questionnaire (IWPQ). The purpose of this research is to do the adaptation process of IWPQ into Indonesian. The procedure in the adaptation process consists of forward translation, synthesis, back translation, back translation review, and cognitive debriefing. Content validity test using Aiken's V shows that all IWPQ items have high Aiken's V. The field test involving 231 employees shows that IWPQ has a good discriminant indexes, ranging from .447 to .734 . The Indonesian version of IWPQ also has a good reliability, in task performance (TP) .871; contextual performance (CP) .858; and counterproductive work behavior (CWB) .814.
\end{abstract}

Keywords: adaptation; IWPQ; measurement; questionnaire; work performance 


\section{Adaptation of Individual Work Performance Questionnaire (IWPQ) into Bahasa Indonesia}

\section{Introduction}

Individual work performance (IWP) is an important aspect of organizations and individuals. An organization needs individuals with high work performance to achieve goals, to increase productivity, and to increase competitiveness (Sonnentag \& Frese, 2002). The higher performance implies efficiency, effectiveness, and higher quality of work (Goodhue \& Thompson, 1995). For individuals, high-performance results in satisfaction and mastery (Sonnentag, Volmer, \& Spychala, 2008). The most widely cited definition of job performance is by Campbell, McHenry, and Wise (1990) revealing that job performance is a behavior or action relevant to the organizational goal. There are three ideas relating to the definition: (1) job performance is defined as a behavior or action, not a result, (2) job performance only includes behavior relevant to organizational goals, and (3) job performance is a multidimensional concept. That definition is consistent with Viswesvaran and Ones (2000) as well as Motowidlo (2003).

Performance appraisal is an important instrument in evaluating work performance covering behavior and outcome of employee (Drewes \& Runde, 2002). From 1998 until 2004, there was an increase in the use of a formal management system of performance appraisal (Prowse \& Prowse, 2009). Performance appraisal was developed from year to year. In 1940s, behavioral approach including Behavioral Anchored Rating Scale (BARS) and Behavioral Evaluation Scale (BES) was developed. In 1945s, performance appraisal was developed into result-oriented. In the 1990s, 360-degree feedback was developed. 360-degree feedback is the most comprehensive method combining multi-rater evaluation involving supervisor, peer, self, and subordinate (Garavan, Morley, \& Flynn, 1997; McDowall \& Fletcher, 2004; Tyson \& Ward, 2004; Padhi \& Sahu, 2013). Besides becoming an important issue in the organization around the world, individual work performance is also an important issue in the field of research (Koopmans, 2014).

Various instruments were developed to measure individual work performance (IWP). However, none of the existing instruments can measure all the relevant aspects of individual work performance (Koopmans, 2015). Besides, the available instruments are only developed for a specific population (e.g., for specific occupation) (Koopmans, 2014). Therefore the existing instruments cannot be generally applied and used for research purpose involving employee from various type of jobs. Errors in psychometric were also found in the available instruments (Appelbaum, Roy, \& Gilliland, 2011). To overcome the limitation of current instruments, Individual Work Performance Questionnaire (IWPQ) is developed (Koopmans, 2014).

At first, Koopmans had done a systematic literary review of the 58 studies to establish a clear definition and conceptualization of IWP (Koopmans et al., 2011). Job performance is a multi-dimensional concept consists of a various performance construct (Borman \& Motowidlo, 1997; Borman, Klimoski, \& Ilgen, 2003; Motowidlo, 2003; Sonnentag et al., 2008). Griffin, Neal, and Parker (2007) revealed the three major dimensions in work performance including proficiency, adaptiveness, and proactivity. Job performance includes behaviors that might have positive effects and behavior possibly having negative effects on organizational accomplishment (Motowidlo, 2003). Based on the systematic review (Koopmans et al., 2011) and on field-testing of the IWPQ (Koopmans et al., 2012), the IWP consists of three dimensions including task performance (TP), contextual performance $(\mathrm{CP})$, and counterproductive work behavior (CWB).

The first dimension is task performance. Task performance can be defined as a proficiency or ability to perform the core or central tasks of the job (Koopmans et al., 2011). This dimension consists of ability in planning and organizing work, quality of work, results-oriented, and ability to work efficiently. Motowidlo (2003) revealed two forms of task performance; one involves activities directly transforming raw material into the goods 
and services. The second involves activities servicing and maintaining technical core. Task performance contributes to the organization's technical core. Another dimension is contextual performance. Contextual performance can be defined as extra behavior and action beyond the main tasks supporting the organization including skills to perform extra tasks, having initiative, taking on challenging tasks, developing knowledge and skills (Koopmans et al., 2011). Contextual performance is different from task performance since its activities are not a formal part of the job description (Sonnentag et al., 2008). However, contextual performance indirectly contributes organizational performance by facilitating task performance. Contextual performance contributes to the organizational effectiveness through its effects on the psychological, social, and organizational work contexts (Motowidlo, 2003). Individuals contribute through the contexts in several ways such as: (1) by influencing others to be more likely perform behavior contributing to organizational effectiveness, (2) by increasing the individual's readiness in performing contribution to organization (e.g., individual develop their knowledge and skill related to job), and (3) by showing an action influencing the organization resources. The other dimension is counterproductive work behavior. Counterproductive work behavior shows a contrast to behavior relevant to the organization's goal (Motowidlo, 2003). Behaviors with a negative value for organizational effectiveness belong to counterproductive work behavior (Viswesvaran \& Ones, 2000). Those behaviors include complaining, doing actions endangering the organization, misusing information, misusing time and resources, unsafe behavior, and poor quality of work.

After getting a clear conceptual framework of individual work performance, Koopmans identified possible indicators of IWP through the scientific literature, existing questionnaire, and expert interview. From 128 indicators, 23 indicators were chosen according to an expert judgment (Koopmans, Bernaards, Hildebrandt, De Vet, \& Van Der Beek, 2014b). The selected indicators were used to construct the first version of Individual Work Performance Questionnaire (IWPQ) resulting the 47-item IWPQ 0.1 (Koopmans et al., 2012). The 47-item IWPQ 0.1 was tested in a sample of 1181 Dutch workers from three occupational sectors: manual worker, service worker, and office worker. Based on the factor analysis, the original conceptual framework with four dimensions was reduced to the three dimensions. The adaptive performance was found as part of the contextual performance (Koopmans et al., 2012). Next, the generic short scales were constructed by involving only items fit to the Rasch model and relevant to all occupation, resulting IWPQ 0.2. Koopmans then improved the IWPQ 0.2 by adding items in each dimension, resulting 27-item IWPQ 0.3 . The 27-item IWPQ 0.3 was tested in 1424 Dutch workers from various jobs. The unfit items based on Rasch analysis were eliminated. From this process, 18-item IWPQ 1.0 was developed (Koopmans, 2014).

\section{Table 1}

Specification of Individual Work Performance Questionnaire (IWPQ) 1.0

\begin{tabular}{lcc}
\hline \multicolumn{1}{c}{ Dimension } & Item & Cronbach's Alpha \\
\hline Task performance (TP) & 5 item & .79 \\
Contextual performance (CP) & 8 item & .83 \\
Counterproductive work behavior (CWB) & 5 item & .89 \\
\hline
\end{tabular}

IWPQ is a self-report measuring individual performance based on individual rating. As a self-report, it has several advantages to solve current performance appraisal's problems. The benefit of using self-report are: (1) self-report can facilitate performance appraisal involving workers from various jobs, (2) self-report is more comprehensive in assessing individual work performance because workers have more opportunity to observe their behaviors, (3) employees are actively involved in the performance appraisal process raising employee's responsibility, and (4) self-report has a positive impact on employee's satisfaction on the fairness of the scoring system. IWPQ was developed for research purposes as a short questionnaire to measure individual work performance in a general population (Koopmans, 2015). Therefore it is suitable for research studies involving workers from different types of jobs. It takes only 3-5 minutes to complete IWPQ consisting of 18 items. The response formats in the task and contextual performance are seldom - sometimes - regularly - often - always. Then in counterproductive work behavior, the response formats are never - seldom - sometimes - regularly often with a range from 0 to 4 . Specification of IWPQ can be seen in 錯誤! 找不到參照來源。 
Widyastuti, T., \& Hidayat, R.

The construct of IWPQ has been tested and the result shows that IWPQ has a good construct validity represented by its convergent and discriminant validity (Koopmans et al., 2014). For wider use of IWPQ out of the native language, IWPQ has been adapted from Dutch to English-American (Koopmans, 2014; Koopmans et al., 2016). The English-American version of IWPQ has also a good psychometric property. Internal consistency with Cronbach Alpha on task performance is .79 , on contextual performance is .83 , and on counterproductive work behavior is .89. In Indonesia, it has not been found detailed information relating to the adaptation process of IWPQ into Indonesia. The purpose of this study is to do the adaptation process of IWPQ into Indonesia.

\section{Method}

\subsection{Participants}

The adaptation process involved four participants consisting of three professional translators and IWPQ developer. In cognitive debriefing or pilot testing, 38 employees were involved. Then in field testing, there were 231 employees from Directorate of Universitas Gadjah Mada, Indonesia filling out the questionnaire. The participants' ages ranged from 21 to 59 years old (mean= 41.7; SD: 9.723). The participants included cleaning staff, driver, accountant, financial staff, administrative staff, technician, secretary, and educational staff.

\subsection{Research procedure}

The adaptation process was done according to adaptation guideline from Beaton, Bombardier, Guillemin, and Ferraz (2000); Wild et al., (2005); and ITC Guidelines for Translating and Adapting Tests (2017). The adaptation process consists of seven stages: (1) requesting a permission to adapt IWPQ into Indonesian from the IWPQ developer, (2) forward translation of IWPQ into Indonesian by two independent professional translators, (3) synthesis process to produce one Indonesian translation, (4) back-translation into original language, (5) back-translation review process by the IWPQ developer, (6) cognitive debriefing on subject with similar characteristics to target, (7) review process of the cognitive debriefing result and finalization. In the psychometric testing process, it had been done three procedures including (1) content validity test, (2) calculation of discriminant indexes of the item, and (3) estimation of reliability coefficient with Cronbach's Alpha.

\section{Result}

\subsection{IWPQ Translation}

The results of IWPQ translation are explained in order. In the translation process of the introductory instruction 'the following questions relate to how you carried out your work ...' both translators had no difficulties. The translation of the items in task performance, contextual performance, and counterproductive work behavior dimension are explained in this following paragraph.

Task Performance - Task performance is revealed through five statements, item number 1 through 5. From five items, one item (item number 5) had been translated identically between the two translators, so it is not discussed. The others translation were dissimilar only in one or two words. Translation of the items in task performance can be seen in Table 2. In item number 1, the difference of translation was found in the translation of the word 'was able'. Translator 1 used 'mampu', while the second translator used 'bisa'. Based on Indonesian dictionary (2008), 'bisa' has the similar meaning with 'mampu' (having a power in doing something). The task performance dimension reveals the ability to perform the main tasks of the work. Therefore, in the synthesis process, the word 'mampu' was considered more appropriate because it reflects a power or ability in doing something. 
Table 2

Translation of items in Task Performance

\begin{tabular}{|c|c|c|c|}
\hline No & Original item & Translation 1 & Translation 2 \\
\hline 1 & $\begin{array}{l}\text { I was able to plan my work } \\
\text { so that I finished it on time. }\end{array}$ & $\begin{array}{l}\text { Saya mampu merencanakan } \\
\text { pekerjaan sehingga dapat } \\
\text { menyelesaikannya tepat waktu }\end{array}$ & $\begin{array}{l}\text { Saya bisa merencanakan pekerjaan } \\
\text { sehingga saya menyelesaikannya } \\
\text { tepat waktu }\end{array}$ \\
\hline 2 & $\begin{array}{l}\text { I kept in mind the work } \\
\text { result I needed to achieve. }\end{array}$ & $\begin{array}{l}\text { Saya terus menanamkan di benak } \\
\text { hasil kerja yang perlu saya capai. }\end{array}$ & $\begin{array}{l}\text { Saya mengingat hasil pekerjaan } \\
\text { yang harus saya capai. }\end{array}$ \\
\hline 3 & I was able to set priorities. & Saya maтри menyusun prioritas & Saya dapat menetapkan prioritas \\
\hline 4 & $\begin{array}{l}\text { I was able to carry out my } \\
\text { work efficiently }\end{array}$ & $\begin{array}{l}\text { Saya mampu melaksanakan } \\
\text { pekerjaan saya secara efisien. }\end{array}$ & $\begin{array}{l}\text { Saya dapat menyelesaikan } \\
\text { pekerjaaan saya secara efisien }\end{array}$ \\
\hline 5 & I managed my time well. & Saya mengatur waktu dengan baik. & $\begin{array}{l}\text { Saya mengatur waktu saya dengan } \\
\text { baik. }\end{array}$ \\
\hline
\end{tabular}

Note. The differences of the translations were printed in bold. Indonesian translations were printed in italic.

Another discussed item is item number 2 in the word 'kept in mind'. Translator 1 used the word 'terus menanamkan di benak', whereas translator 2 used the word 'mengingat'. Both of them have the same meaning. In the synthesis process, researchers decided to use the word 'terus mengingat' considered more familiar to the subject. The word 'work result' was translated as 'hasil kerja' by both translators. In the synthesis process, it was decided to use the word 'target kerja' because the word 'hasil kerja' is less familiar. Besides, the word 'target kerja' reflects the meaning of 'the work result I needed to achieve.'

The translation difference in item number 3 was in the word 'set'. Translator 1 used the word 'menyusun', while the second translator used the word 'menetapkan'. The word 'menetapkan' was considered more appropriate to explain 'priorities'. In item 4, the different translation was found in the translation of the word 'carry out'. Translator 1 used the word 'melaksanakan', while the second translator used the word 'menyelesaikan'. In Online Cambridge Dictionary, 'carry out' is defined as 'to accomplish'. Both translations fit the meaning in the dictionary. In the synthesis process, the word 'menyelesaikan' is considered more appropriate to describe 'carry out work'.

Contextual Performance - The translation of items in the dimension of contextual performance has the similar meaning, especially in item 12. Therefore in this section, item number 12 was not discussed. The translation of items in contextual performance can be seen in Table 3. In the translation of item number 6, the differences were found in the translation of words 'on my initiative' and 'my old tasks'. Translator 1 translated 'on my initiative' into 'dengan inisiatif sendiri', while translator 2 translated it into 'atas prakarsa sendiri'. Referring to Indonesian dictionary (2008), 'initiative' is a 'first attempt'. The word 'atas prakarsa sendiri' was considered more appropriate. The next discussion was the translation of word 'my old tasks', translator 1 translated it into 'tugas sebelumnya', while translator 2 translated it into 'tugas lama'. Both words have similar meaning. In the synthesis process, the word 'tugas lama' was selected to emphasize the meaning of 'old tasks'.

The next discussion is item number 7. The different translations were found in the sentence structure and the translation of the word 'took on'. Translator 1 used the word 'bersedia menerima', meanwhile translator 2 used the word 'mengambil'. Both translations had the meaning of 'the willingness to carry out the task'. In order to get an understandable sentence, the phrase was rearranged into 'saya bersedia menjalankan tugas-tugas yang menantang yang ditawarkan pada saya.'

In Table 3 items number 8 and 9, the difference of translation was found in the word 'up-to-date'. Item number 8 discusses about 'knowledge' while item number 9 is about 'work skills'. In translating 'up-to-date', translator 1 used the word 'memperbarui' while the second translator used the word 'tetap aktual'. According to Online Cambridge dictionary, 'up-to-date' was interpreted as 'modern and in touch with the latest ideas'. The word 'memperbarui' and 'menjaga tetap aktual' have similar meaning. In the synthesis process, the word 'memperbarui' was appraised more familiar in everyday language. 
Widyastuti, T., \& Hidayat, R.

Table 3

Translation of Items in Contextual Performance

\begin{tabular}{|c|c|c|c|}
\hline No & Original item & Translation 1 & Translation 2 \\
\hline 6 & $\begin{array}{l}\text { On my initiative, I started } \\
\text { new tasks when my old tasks } \\
\text { were completed. }\end{array}$ & $\begin{array}{l}\text { Dengan inisiatif sendiri, saya } \\
\text { mulai mengerjakan tugas baru } \\
\text { setelah tugas sebelumnya selesai. }\end{array}$ & $\begin{array}{l}\text { Atas prakarsa saya, saya memulai } \\
\text { tugas baru ketika tugas lama saya } \\
\text { selesai. }\end{array}$ \\
\hline 7 & $\begin{array}{l}\text { I took on challenging tasks } \\
\text { when they were available. }\end{array}$ & $\begin{array}{l}\text { Ketika ada tugas yang menantang, } \\
\text { saya bersedia menerimanya }\end{array}$ & $\begin{array}{l}\text { Saya mengambil tugas menantang } \\
\text { ketika ada. }\end{array}$ \\
\hline 8 & $\begin{array}{l}\text { I worked on keeping my } \\
\text { job-related knowledge up-to- } \\
\text { date }\end{array}$ & $\begin{array}{l}\text { Saya berusaha terus memperbarui } \\
\text { pengetahuan terkait pekerjaan } \\
\text { saya }\end{array}$ & $\begin{array}{l}\text { Saya berusaha untuk menjaga } \\
\text { pengetahuan tentang pekerjaan saya } \\
\text { tetap aktual. }\end{array}$ \\
\hline 9 & $\begin{array}{l}\text { I worked keeping my work } \\
\text { skills up-to-date. }\end{array}$ & $\begin{array}{l}\text { Saya berusaha terus memperbarui } \\
\text { keterampilan kerja saya }\end{array}$ & $\begin{array}{l}\text { Saya berusaha untuk menjaga } \\
\text { keterampilan kerja saya tetap } \\
\text { aktual. }\end{array}$ \\
\hline 10 & $\begin{array}{l}\text { I came up with creative } \\
\text { solutions for new problems }\end{array}$ & $\begin{array}{l}\text { Saya mendapatkan solusi kreatif } \\
\text { untuk masalah-masalah baru. }\end{array}$ & $\begin{array}{l}\text { Saya menemukan solusi kreatif } \\
\text { untuk masalah baru. }\end{array}$ \\
\hline 11 & I took on extra responsibilities & $\begin{array}{l}\text { Saya bersedia menerima tanggung } \\
\text { jawab ekstra }\end{array}$ & $\begin{array}{l}\text { Saya mengambil tanggung jawab } \\
\text { ekstra. }\end{array}$ \\
\hline 12 & $\begin{array}{l}\text { I continually sought new } \\
\text { challenges in my work. }\end{array}$ & $\begin{array}{l}\text { Saya terus-menerus mencari } \\
\text { tantangan baru dalam pekerjaan } \\
\text { saya }\end{array}$ & $\begin{array}{l}\text { Saya terus mencari tantangan baru } \\
\text { dalam pekerjaan saya. }\end{array}$ \\
\hline 13 & $\begin{array}{l}\text { I actively participated in } \\
\text { meetings and/or consultations }\end{array}$ & $\begin{array}{l}\text { Saya terlibat aktif dalam rapat } \\
\text { dan/atau konsultasi }\end{array}$ & $\begin{array}{l}\text { Saya aktif berpartisipasi dalam } \\
\text { pertemuan dan atau konsultasi. }\end{array}$ \\
\hline
\end{tabular}

Note. The differences of translations were printed in bold. Indonesian translations were printed in italic.

In item number 10, the difference was in the translation of the word 'came up'. Translator 1 used the word 'mendapatkan' while the second translator used the word 'menemukan'. Based on Indonesian dictionary (2008), 'menemukan' has a meaning of 'getting something that has not existed before'. Based on these references, the words 'mendapatkan' and 'menemukan' are similar in meaning. In the synthesis process, the word 'menemukan' was used to emphasize the effort in finding a solution.

The next difference of translation was in the word 'took on' in item 11. The difference of translation was also found in the previous item, number 7 . The translator 1 used the word 'bersedia menerima', while the second translator used the word 'mengambil'. The definition of the contextual performance is the ability to perform tasks out of the main task indicated by the initiative. The word 'mengambil' was considered more appropriate. The last item discussed in the contextual performance dimension is item number 13. The difference of translation was in the word 'actively participated'. Translator 1 used the word 'terlibat aktif' while the second translator used the word 'aktif berpartisipasi'. Both translations have similar in meaning. In the synthesis process through discussion, it was decided to use the word 'terlibat aktif'.

Counterproductive Work Behavior - In contrast to the previous two dimensions containing positive behaviors supporting the achievement of organizational goals, the counterproductive work behavior dimension contains the opposite negative behaviors and may harm the organization. This dimension was revealed through five items, item number 14 to 18 . Of the five items, three items were identically translated while the two items were discussed because of the difference in translation. The translation of item in counterproductive work behavior can be seen in Table 4.

The two items discussed are item number 14 and 15. First, in item 14 the difference of translation lies in the word 'minor issues'. Translator 1 translated it into 'hal-hal remeh', while the second translator used word 'masalah ringan'. Based on Cambridge Dictionary Online, 'minor' can be defined as 'less, or little, in importance, size etc.' According to the reference, both translations fulfill the meaning of 'minor'. Based on the discussion, it was decided to use the word 'hal-hal remeh' to represent 'minor issues'.

The next discussion is item number 15. The difference of translation was found in the translation 'made problems bigger'. Translator 1 translated it to 'membesar-besarkan masalah', whereas translator 2 translated to 
Adaptation of Individual Work Performance Questionnaire (IWPQ) into Bahasa Indonesia

'membuat lebih banyak masalah'. Both translations had slightly different meanings, 'membesar-besarkan masalah' means to think of or spit the problem to look bigger than it actually is. The translation 'membuat lebih banyak masalah' means creating more problems. Based on the discussion, the first translation has the closest meaning to 'made problems bigger'.

\section{Table 4}

Translation of Items in Counterproductive Work Behavior

\begin{tabular}{|c|c|c|c|}
\hline No & Original item & Translation 1 & Translation 2 \\
\hline 14 & $\begin{array}{l}\text { I complained about minor } \\
\text { work-related issues at work. }\end{array}$ & $\begin{array}{l}\text { Saya mengeluhkan hal-hal remeh } \\
\text { terkait pekerjaan di tempat kerja }\end{array}$ & $\begin{array}{l}\text { Saya mengeluh tentang masalah ringan } \\
\text { mengenai pekerjaan di tempat kerja. }\end{array}$ \\
\hline 15 & $\begin{array}{l}\text { I made problems at work } \\
\text { bigger than they were. }\end{array}$ & $\begin{array}{l}\text { Saya membesar-besarkan masalah di } \\
\text { tempat kerja }\end{array}$ & $\begin{array}{l}\text { Saya membuat lebih banyak masalah } \\
\text { dari mereka di tempat kerja. }\end{array}$ \\
\hline 16 & $\begin{array}{l}\text { I focused on the negative } \\
\text { aspects of situation at work } \\
\text { instead of the positive aspects }\end{array}$ & $\begin{array}{l}\text { Saya berfokus pada aspek negatif } \\
\text { situasi kerja ketimbang aspek } \\
\text { positifnya }\end{array}$ & $\begin{array}{l}\text { Saya lebih fokus pada aspek negatif } \\
\text { ketimbang aspek positif pada situasi di } \\
\text { tempat kerja. }\end{array}$ \\
\hline 17 & $\begin{array}{l}\text { I talked to colleagues about the } \\
\text { negative aspects of my work. }\end{array}$ & $\begin{array}{l}\text { Saya membicarakan aspek negatif } \\
\text { pekerjaan saya dengan rekan-rekan } \\
\text { kerja saya }\end{array}$ & $\begin{array}{l}\text { Saya berbicara dengan para kolega } \\
\text { tentang aspek negatif dari pekerjaan } \\
\text { saya }\end{array}$ \\
\hline 18 & $\begin{array}{l}\text { I talked to people outside the } \\
\text { organization about the negative } \\
\text { aspects of my work }\end{array}$ & $\begin{array}{l}\text { Saya membicarakan aspek-aspek } \\
\text { negatif pekerjaan saya dengan } \\
\text { orang-orang di luar organisasi. }\end{array}$ & $\begin{array}{l}\text { Saya berbicara dengan orang-orang di } \\
\text { luar organisasi tentang aspek negatif } \\
\text { dari pekerjaan saya }\end{array}$ \\
\hline
\end{tabular}

\subsection{Back Translation Result}

The result from the synthesis process was translated back to English. The back translation result then was reviewed by Linda Koopmans, the IWPQ developer, via electronic mail (e-mail). The back translation result was compared with the original English version of IWPQ by reviewing its equivalent and conformity. In this process, the translated items were appraised to have a similar meaning to the original item.

\subsection{The Result of Content Validity Test}

The content validity test was done by 25 raters with a background in Psychology. According to the results of the content validity test with Aiken, all IWPQ translated items have a good Aiken's V, with an average of .82. Based on Aiken (1985), with 25 raters and significance level of .009, Aiken's V must be equal or higher than .67. Thus the 18 items in IWPQ have good content validity. In the content validity test, the involved raters also provided the input for the item revision. Of the 18 items, 13 items were considered appropriate, while the five items got a suggestion for revision, i.e. item number 5, 6, 13, 14, and 18. The revised items can be seen in Table 5.

\section{Table 5}

The Revised Items after Content Validity Test

\begin{tabular}{|c|c|c|}
\hline No & Synthesis Result & Revised Item after Content Validity \\
\hline 5 & Saya mampu mengatur waktu dengan baik & Saya mampu mengatur waktu kerja dengan baik \\
\hline 6 & $\begin{array}{l}\text { Atas prakarsa sendiri, saya memulai tugas baru setelah } \\
\text { tugas lama selesai }\end{array}$ & $\begin{array}{l}\text { Saya bernisiatif memulai tugas baru setelah tugas } \\
\text { sebelumnya selesai }\end{array}$ \\
\hline 13 & Saya terlibat aktif dalam rapat dan atau konsultasi. & Saya terlibat aktif dalam rapat atau koordinasi. \\
\hline 14 & $\begin{array}{l}\text { Saya mengeluhkan hal-hal remeh terkait pekerjaan di } \\
\text { tempat kerja }\end{array}$ & $\begin{array}{l}\text { Saya mengeluhkan hal-hal kecil terkait pekerjaan di } \\
\text { tempat kerja }\end{array}$ \\
\hline 18 & $\begin{array}{l}\text { Saya membicarakan aspek-aspek negatif dalam } \\
\text { pekerjaan dengan orang-orang di luar tempat kerja } \\
\text { saya }\end{array}$ & $\begin{array}{l}\text { Saya membicarakan hal-hal negatif dalam pekerjaan } \\
\text { dengan orang-orang di luar tempat kerja saya }\end{array}$ \\
\hline
\end{tabular}


Widyastuti, T., \& Hidayat, R.

In item number 5, the use of the word 'mengatur waktu' was appraised to have a general meaning. It did not explain the context of time (waktu) relating the job. Then it was revised as 'mengatur waktu kerja' to capture the context of time in work. Then in item number 6, the word 'prakarsa' was considered less familiar so it was replaced by the word 'inisiatif'. In item 13, the raters considered that the use of conjunction 'dan atau' was possibly appraised ambiguous by the subject, thus it was revised as 'rapat atau koordinasi'. Then, in item number 14, the raters gave a note related to the use of 'remeh'. The word 'remeh' impresses a negative meaning with a high social desire, and then it was revised as 'kecil'. In item number 18, the word 'aspek-aspek' was replaced by 'hal-hal' because the word 'aspek-aspek' is less familiar.

\subsection{The Result of Cognitive Debriefing}

The subjects in the cognitive debriefing were 38 employees of Faculty of Psychology in Universitas Gadjah Mada. In this stage, the subjects were invited into one room to fill out the translated IWPQ. In the end of the session, the subjects were asked if there was an ambiguous and confusing item. During the cognitive debriefing, the subjects understood the instructions and items. There were three items with notes to be revised.

\subsection{Finalization Result}

According to the result of cognitive debriefing, the final item of the Indonesian version of IWPQ was revised. The revisions were made in three items namely item number 9,13 , and 14 . The revision was done to ease the subjects to understand the items. The finalization item can be seen in Table 6 .

\section{Table 6}

Finalization of the Indonesian version of IWPQ

\begin{tabular}{|c|c|c|}
\hline No & Revised Item after Content Validity & Finalization \\
\hline 9 & $\begin{array}{l}\text { Saya berusaha terus memperbarui keterampilan } \\
\text { kerja saya. }\end{array}$ & $\begin{array}{l}\text { Saya berusaha terus memperbarui keterampilan } \\
\text { terkait pekerjaan saya. }\end{array}$ \\
\hline 13 & Saya terlibat aktif dalam rapat atau kordinasi. & $\begin{array}{l}\text { Saya berpartisipasi aktif dalam rapat atau } \\
\text { pertemuan }\end{array}$ \\
\hline 14 & $\begin{array}{l}\text { Saya mengeluhkan hal-hal kecil terkait } \\
\text { pekerjaan di tempat kerja }\end{array}$ & $\begin{array}{l}\text { Saya mengeluhkan persoalan-persoalan kecil } \\
\text { dalam pekerjaan saya }\end{array}$ \\
\hline
\end{tabular}

\subsection{The Result of Field Testing}

Subjects of nine Directorates of Universitas Gadjah Mada were involved in the field test of the Indonesian version of IWPQ. Of the 266 questionnaires, the returned questionnaires were 239 (89.85\%). Of 239 returned questionnaires, 7 questionnaires were not filled completely, and then one data was an outlier, so it was not included in the analysis. Of the 231 subjects, 121 subjects $(52.4 \%)$ were male, 86 subjects (37.2\%) were female, and 24 subjects $(10.4 \%)$ did not fill the gender identity. The subjects' ages ranged from 21 to 59 years (mean= 41.70, SD = 9.723). The subjects' occupations or types of job range from cleaning service officer, drivers, accountants, finance staff, administrative staff, technicians, secretaries, verifiers, and educational staff.

All items in IWPQ Indonesian version have good discriminant indexes (above .3). In the task performance, item number 1 to 5, the discriminant index ranges from .665 to .734. Then on the contextual performance, items number 6 through 13, the discriminant index ranges from .447 to .719 . Then, in the counterproductive work behavior, item number 14 to 18 , the discriminant index ranges from .484 to .659 . The discriminant index can be seen in Table 7.

The reliability coefficient of the Indonesian version of IWPQ was calculated using Cronbach's Alpha. The reliability coefficient and standard error of measurement for each IWPQ dimension can be seen in Table 7. The 
Adaptation of Individual Work Performance Questionnaire (IWPQ) into Bahasa Indonesia

reliability coefficient on task performance dimension is .871 with the standard errors of measurement of .227 . Then in the dimension of contextual performance, the reliability coefficient is .858 with a standard error of measurement of .195. Finally, the counterproductive work behavior dimension, the opposite dimension of the other two dimensions, obtained reliability coefficient of .814 with a standard error of measurement of .129.

Table 7

Discriminant Index and Reliability of $\operatorname{IWPQ}(N=231)$

\begin{tabular}{llcccc}
\hline No & \multicolumn{1}{c}{ Dimension } & Total Item & Discriminant Index & Reliability & SEm \\
\hline 1 & Task performance & 5 & $.665-.734$ & .871 & .227 \\
2 & Contextual performance & 8 & $.447-.719$ & .858 & .195 \\
3 & Counterproductive work behavior & 5 & $.484-.659$ & .814 & .129 \\
\hline
\end{tabular}

\section{Discussion}

The items in the Indonesian version of IWPQ have good discriminant index ranging from .447 to .734 . This is consistent with the item selection criteria of Azwar (2016) that the good test must have a minimum discriminant index of .30. The reliability coefficients using Cronbach's alpha in the three dimensions of IWPQ; task performance dimension, contextual performance, and counterproductive work behavior meet the established standards. The reliability coefficients of the three dimensions of IWPQ fit the criteria of Wells and Wollack (2003) revealing that low stakes test must have a minimum internal consistency of .800 or .850 . It is also in accordance with Urbina (2004) explaining that most test users determined that the test should have a minimum reliability coefficient of .8 or higher. The Indonesian version of IWPQ has reliability coefficient or accuracy as well as the English-American IWPQ and the Dutch version (Koopmans, 2014).

Response Format - Response format in the Indonesian version of IWPQ is slightly different from the English version of IWPQ. The final response format of the Indonesian version of IWPQ in task and contextual performance dimensions is 'jarang - kadang - sering - sangat sering - selalu'. The response format was modified because the response sequence in Indonesians is slightly different from the original version. In the English-American IWPQ version, the 'regularly' response is appraised as middle response and has a lower frequency than 'often'. However, based on the rating of 41 raters, the 'regularly' response was appraised to have a higher frequency of occurrences than 'often'. To avoid multiple interpretation and ambiguous meaning, the 'regularly' response is eliminated. Then 'sering sekali' as the translation of 'very often' was added in the final response format in Indonesian version of IWPQ to maintain the response sequence from the lowest (jarang) frequency to the highest (selalu).

Practical Using and Scoring - The Indonesian version of IWPQ was developed for research purposes as a short questionnaire to measure the individual work performance comprehensively in the general working population. The Indonesian version of IWPQ consists of 18 items. It takes 3 to 5 minutes to complete IWPQ. IWPQ's three dimensions namely task performance, contextual performance, and counterproductive work behavior were translated into Performansi Tugas (PT), Performansi Kontekstual (PK), and Perilaku Kerja Kontraduktif (PKK). The scoring of the Indonesian version of IWPQ is similar to IWPQ Dutch and English version (Koopmans, 2015). IWPQ subscale scores were calculated by summing the scores of all items in each subscale, and then divided by the number of items in the subscale. A subscale score ranging from 0 to 4 with a high score reflects the height of the dimension. Separated scores of each dimension facilitate the interpretation of the PKK subscale and ease to compare the scores of the dimensions. The total IWPQ score was calculated by the formula: PT + PK + (4 - PKK). The average total scores range from 0 (low) to 12 (high). The formula to obtain the score for each dimension in IWPQ can be seen in Table 8 . 
Widyastuti, T., \& Hidayat, R.

\section{Table 8}

Scoring of IWPQ subscale

\begin{tabular}{ll}
\hline \multicolumn{1}{c}{ Dimension } & \multicolumn{1}{c}{ Scoring formula } \\
\hline Performansi tugas & (Item $1+2+3+4+5) / 5$ \\
Performansi kontekstual & (Item $6+7+8+9+10+11+12+13) / 8$ \\
Perilaku kerja kontraproduktif & (Item $14+15+16+17+18) / 5$ \\
\hline
\end{tabular}

\section{Conclusion}

Based on the results of the study, a well-adapted Individual Work Performance Questionnaire (IWPQ) was obtained. It is demonstrated by psychometric properties of the Indonesian version of IWPQ, such as content validity, discriminant index, and reliability coefficient meeting the established standards. IWPQ was developed for research purposes as a short questionnaire to measure the individual work performance of the employees with specific job types and various types of work. For workplace using, IWPQ can be used as a self-assessment instrument to complement other performance appraisal procedures, such as key performance indicators and 360-degree feedback. Further study is needed to test IWPQ Indonesian version in a larger and more various sample because the subjects in this study are limited to only employees in Directorate of Universitas Gadjah Mada. Indonesia version of IWPQ can also be tested using multi-trait multi-method strengthening or adding the evidence that IWPQ measures the appropriate construct as its measure purposes.

Acknowledgments: The researchers thank to the Indonesian Endowment Fund for Education (LPDP) of Ministry of Finance of the Republic of Indonesia to financially support this research.

\section{References}

Aiken, L. R. (1985). Three coefficients for analyzing the reliability and validity of ratings. Educational and Psychological Measurement, 45(1), 131-142. https://doi.org/10.1177/0013164485451012

Appelbaum, S. H., Roy, M., \& Gilliland, T. (2011). Globalization of performance appraisals: Theory and applications. Management Decision, 49(4), 570-585. https://doi.org/10.1108/00251741111126495

Azwar, S. (2016). Penyusunan skala psikologi [Constructing a psychological scale]. Yogyakarta: Pustaka Pelajar.

Beaton, D. E., Bombardier, C., Guillemin, F., \& Ferraz, M. B. (2000). Guidelines for the process of cross-cultural adaptation of self-report measures. Spine, 25(24), 3186-3191. https://doi.org/10.1097/00007632-200012150-00014

Borman, W. C., Klimoski, R. J., \& Ilgen, D. (2003). Stability and change in Industrial and Organizational Psychology. In I. B. Weiner, W. C. Borman, D. R. Ilgen, \& R. J. Klimoski (Eds.), Handbook of Psychology: Industrial and Organizational Psychology (Vol. 12, pp. 1-17). USA: John Wiley \& Sons. https://doi.org/10.1002/0471264385.wei1201

Borman, W., \& Motowidlo, S. (1997). A theory of individual differences in task and contextual performance. Human Performance, 10(2), 99-109. https://doi.org/10.1207/s15327043hup1002_3

Campbell, J. P., McHenry, J. J., \& Wise, L. L. (1990). Modeling job performance in a population of jobs. Personnel Psychology, 43(2), 313-575. https://doi.org/10.1111/j.1744-6570.1990.tb01561.x

Carry out. (n.d.). In Cambridge Dictionary online. Retrieved from https://dictionary.cambridge.org/us/dictionary/english-indonesian/carry?q=carry\%2Bout

Drewes, G., \& Runde, B. (2002). Performance Appraisal. In S. Sonnentag (Ed.), Psychological management of individual performance (pp. 137-154). Chichester; New York: John Wiley \& Sons.

Garavan, T. N., Morley, M., \& Flynn, M. (1997). 360-degree feedback: Its role in employee development. Journal of Management Development, 16(2), 134-147. https://doi.org/10.1108/02621719710164300

Goodhue, D. L., \& Thompson, R. L. (1995). Task-technology fit and individual performance. Management 
Adaptation of Individual Work Performance Questionnaire (IWPQ) into Bahasa Indonesia

Information Systems Research (MIS) Quarterly, 19(2), 213-236. https://doi.org/10.2307/249689

Griffin, M. A., Neal, A., \& Parker, S. K. (2007). A new model of work role performance: Positive behavior in uncertain and interdependent contexts. Academy of Management Journal, 50(2), 327-347. https://doi.org/10.5465/amj.2007.24634438

ITC Guidelines for Translating and Adapting Tests (Second Edition). (2017). International Journal of Testing, 1-34. https://doi.org/10.1080/15305058.2017.1398166

Koopmans, L. (2014). Measuring individual work performance. Amsterdam: Department of Public and Occupational Health Vrije Universiteit University Medical Center.

Koopmans, L. (2015). Individual Work Performance Questionnaire - Instruction manual. Amsterdam: TNO Innovation for Life- Vrije Universiteit University Medical Center.

Koopmans, L., Bernaards, C. M., Hildebrandt, V. H., De Vet, H. C. W., \& Van Der Beek, A. J. (2014a). Construct validity of the individual work performance questionnaire. Journal of Occupational and Environmental Medicine, 56(3), 331-337. https://doi.org/10.1097/JOM.0000000000000113

Koopmans, L., Bernaards, C. M., Hildebrandt, V. H., De Vet, H. C. W., \& Van Der Beek, A. J. (2014b). Measuring individual work performance: Identifying and selecting indicators. Work, 48(2), 229-238.

Koopmans, L., Bernaards, C. M., Hildebrandt, V. H., Lerner, D., De Vet, H. C. W., \& Van Der Beek, A. J. (2016). Cross-cultural adaptation of the Individual Work Performance Questionnaire. Work, 53(3), 609-619. https://doi.org/10.3233/WOR-152237

Koopmans, L., Bernaards, C. M., Hildebrandt, V. H., Schaufeli, W. B., De Vet Henrica, C. W., \& Van Der Beek, A. J. (2011). Conceptual frameworks of individual work performance: A systematic review. Journal of Occupational and Environmental Medicine, 53(8), 856-866. https://doi.org/10.1097/JOM.0b013e318226a763

Koopmans, L., Bernaards, C., Hildebrandt, V., van Buuren, S., van der Beek, A. J., \& de Vet, H. C. W. (2012). Development of an individual work performance questionnaire. International Journal of Productivity and Performance Management, 62(1), 6-28. https://doi.org/10.1108/17410401311285273

McDowall, A., \& Fletcher, C. (2004). Employee development: An organizational justice perspective. Personnel Review, 33(1), 8-29. https://doi.org/10.1108/00483480410510606

Minor. (n.d). In Cambridge Dictionary online. Retrieved from https://dictionary.cambridge.org/us/dictionary/english-indonesian/minor

Motowidlo, S. J. (2003). Job performance. In I. B. Weiner, W. C. Borman, D. R. Ilgen, \& R. J. Klimoski (Eds.), Handbook of psychology: Industrial and organizational psychology (Vol. 12, pp. 39-52). USA: John Wiley \& Sons. https://doi.org/10.1002/0471264385.wei1203

Padhi, S. K., \& Sahu, P. C. (2013). 360-degree feedback performance appraisal in Management Educational Institution- A study. Resource, 32, 352-373.

Prowse, P., \& Prowse, J. (2009). The dilemma of performance appraisal. Measuring Business Excellence, 13(4), 69-77. https://doi.org/10.1108/13683040911006800

Pusat Bahasa Departemen Pendidikan Nasional. (2008). Kamus bahasa Indonesia [Indonesian dictionary] (Vol. 1). Jakarta.

Sonnentag, S., \& Frese, M. (2002). Performance: Concept, theory, and predictors. In S. Sonnentag (Ed.), Psychological management of individual performance (pp. 3-26). Chichester, New York: John Wiley \& Sons. https://doi.org/10.1002/0470013419

Sonnentag, S., Volmer, J., \& Spychala, A. (2008). Job performance. The SAGE handbook of organizational behavior, 1, 427-447. https://doi.org/10.4135/9781849200448

Tyson, S., \& Ward, P. (2004). The use of 360-degree feedback technique in the evaluation of management development. Management Learning, 35(2), 205-223. https://doi.org/10.1177/1350507604043025

Up-to-date. (n.d). In Cambridge Dictionary online. Retrieved from https://dictionary.cambridge.org/us/dictionary/english-indonesian/up_1?q=up\%2Bto\%2Bdate

Urbina, S. (2004). Essentials of psychological testing. Hoboken, N.J: John Wiley \& Sons.

Viswesvaran, C., \& Ones, D. S. (2000). Perspectives on models of job performance. International Journal of Selection and Assessment, 8(4), 216-226. https://doi.org/10.1111/1468-2389.00151 
Widyastuti, T., \& Hidayat, R.

Wells, C. S., \& Wollack, J. A. (2003). An instructor's guide to understanding test reliability. Testing \& Evaluation Services. University of Wisconsin.

Wild, D., Grove, A., Martin, M., Eremenco, S., McElroy, S., Verjee-Lorenz, A., \& Erikson, P. (2005). Principles of good practice for the translation and cultural adaptation process for patient-reported outcomes (PRO) measures : Report of the ISPOR task force for translation and cultural adaptation. Value in Health, $8(2)$, 94-104. https://doi.org/10.1111/j.1524-4733.2005.04054.x 